\title{
Kriteria Memilih Pasangan Hidup Menurut Hadits Riwayat Imam Al- Bukhari dan Implikasinya terhadap Pendidikan Pranikah
}

\author{
Rossa Roudhatul Jannah*, Enoh \\ Prodi Pendidikan Agama Islam, Fakultas Tarbiyah dan Keguruan, Universitas \\ Islam Bandung, Indonesia.
}

*Rossarj29@gmail.com, enuroni@gmail.com

\begin{abstract}
Having a life partners the Instinct of every human being, without this instinct perhaps the earth will not be inhabited. its sunnaitulllah that between men and women there is an element of attraction and the need to complement each other. To meet the needs of complementarity, it is necessary to have a valid and lawful partner, the way is through marriage. Choosing a partner is the beginning to find a soulmate and become the path to a marriage. it has become a tradition in Java when looking for a life partner, which is generally considered in terms of outward appearances such as bebet seeds and weight. These three things become a kind of calibration tool for the Javanese to determine which prospective son-in-law is good for his child. This study aims to (1) explore the hadith narrated by imam Bukhari about choosing a life partner according to the Muhaditsin (2) Explore the essence of the criteria in choosing a life partner according to the hadith narrated by imam Bukhari (3) Express the opinion of experts regarding the criteria for choosing a partner and its relation to premarital education (4) dentifying the implications in choosing a life partner contained in the hadith narrated by imam al-Bukhari on premarital education. This situdy uses a qualitative approach with descriptive analytic characteristics, with research techniques using the tautsiq method, the tashih method, the takhrij method, the date method, the tahlili method, the takwil method, and the tathbiq method. The results of the study suggest that the essence of the Hadith History of Bukhari no. $4700 \mathrm{~s}$ (1) Humanly a man or woman can be attracted by the opposite sex because of wealth, beauty or good looks, descent, and diversity. (2) islam teaches to prioritize religious factors as a criterion for choosing a life partner in building a household. (3) it is mportant for every young man to be aware of the pillars in the household. The implications of premarital education from the hadith narrated by Bukhari regarding the criteria for choosing a life partner are as follows: (1) The Purpose of Premarital Education in Ruinining Household Life, (2) Benefits of Premarital Education Materials in Overcoming the Problems of Domestic Life, (3) Viritue choose a partner.
\end{abstract}

Keywords: HR Bukhari no.4700, Criteria, Choosing a Partner, implications, Premarital Education.

\begin{abstract}
Abstrak. Memiliki pasangan hidup itu adalah naluri setiap manusia, tanpa ada naluri ini mungkin bumi tidak akan berpenghuni. Sudah menjadi sunnaitulllah bahwa antara laki-laki dan wanita tersebut terdapat unsur tarik menarik dan kebutuhann untuk saling melengkapi. untuk memenuhi kebutuhann saling melengkapi, maka diperlukan pasangan sah dan halal jalannya adalah melalui pernikahann. Memilih pasangan merupakan awal untuk menemukan tambatan hati dan menjadi jalan menuju sebuah pernikahan. Sudah menjadi tradisi di Jawa ketika mencari pasangan hidup itu yang diperhatikan umumnya dari segi lahiriah seperti bibit bebet dan bobot. Ketiga hal tersebut menjadi semacam alat kalibrasi bagi orang Jawa untuk menentukan calon menantunya yang baik bagi anaknya. Penelitian ini bertujuan untuk (1) Menggali syarah hadits riwayat imam Bukhari tentang memilih pasangan hidup menurut para Muhaditsin (2) Menggali esensi kriteria dalam memilih pasangan hidup menurut hadits riwayat imam Bukhari (3) Mengemukakan pendapat para ahli mengenai kriteria memilih pasangan dan kaitannya dengan pendidikan pranikah (4) Mengidentifikasi implikasi dalam memilih pasangan hidup yang terkandung dalam hadits riwayat imam al-Bukhari terhadap pendidikan pranikah. Penelitian ini menggunakkan pendekatan kualitatif yang becirikan deskriptif analitik, dengan teknik penelitian menggunakkan metode tautsiq, metode tashih, metode takhrij, metode tarikh, metode tahlili, metode takwil ,dan metode tathbiq. Hasil penlitian mengemukakan bahwa esensi dari Hadits Riwayat Bukhari no 4700 adalah (1) Secara manusiawi seorang laki-laki atau wanita dapat tertarik oleh lawan jenis karena harta, kecantikan atau ketampanan, keturunan, dan keberagamaan.(2) islam mengajarkan untuk mengutamakan faktor keberagamaan sebagai kriteria pemilihan pasanagan hidup dalam membangun rumah tangga. (3) Penting bagi setiap pemuda-pemudi menyadari pilar-pilar dalam rumah tangga. Adapun yang menjadi implikasi pendidikan pranikah dari hadits riwayat Bukhari tentang kriteria memilih pasangan hidup adalah sebagai berikut : (1) tujuan Pendidikan Pranikah Dalam Menjalankan Kehidupan Berumah Tangga, (2) Manfaat Materi Pendidikan Pranikah dalam Mengatasi Problematika Kehidupan Rumah Tangga, (3) Keutamaan dalam memilih pasangan.
\end{abstract}

Kata Kunci: H.R Bukhari no.4700, Kriteria, Memilih Pasangan, implikasi, Pendidikan Pranikah 


\section{A. Pendahuluan}

Memiliki pasangain hidup itu adalah naluri setiap manusia, tanpa ada naluri ini mungkin bumi tidak akan berpenghuni. Sudah menjadi sunnaitulllah bahwa antara laki-laki dan wanita tersebut terdapat unsur tarik menarik dan kebutuhan ini untuk saling melengkapi. memenuhi kebutuhann saling melengkapi, maka diperlukan pasangan sah dan halal jalannya adalah melalui pernikahann.

Menurut Yusufial Qardawi (2004:22) Pernikahann adalah barat dua sayap. Sayap athifah (rasa cinta) dan sayap akal. Sayapiathifah yang paling rendah adalah qabul (bisa menerima lamaran) dan tidak membuat pelamar menjauh dan yang tertinggi adalah adanya perasaan cenderung kepada lawan jenis. Sedangkan sayap akal meliputi takafu' (kecocokan) pada status sosial, ekonomi, pendidikan, psikologis dan gen (garis keturunan). Bahkan mencangkup seperti warna kulit, tinggi, kurus dan lain-lain.

Telah dijelaskan di dalam Undang-undang Nomor 1 Tahun 1974 bahwa pernikahann adalah sebuah katan lahir bathin antara seorang pria dan seorang wanita sebagai suami stri dengan tujuan membentuk keluarga (rumah tangga) yang bahagia dan kekal berdasarkan keituhanan Yang Maha Esa. Menurut Dyer (1983), pernikahann adalah suatu subsistem dari hubungan yang luas dimana dua orang dewasa dengan jenis kelamin berbeda membuat sebuah komitmen personal dan legal untuk hidup bersama sebagai suami dan stri.

Memilih pasangan merupakan awal untuk menemukan tambatan hati dan menjadi jalan menuju sebuah pernikahann. Sudah menjadi tradisi di Jawa ketika mencari pasangan hidup itu yang diperhatikan umumnya dari segi lahiriah seperti bibit bebet dan bobot. Ketiga hal tersebut menjadi semacam alat kalibrasi bagi orang Jawa untuk menentukan calon menantunya yang baik bagi anaknya.

Sedangkan dalam hadits riwayat Imam Bukhari No.4700 dalam kitab nikah pada bab sekufu dalam agama, tentang memilih pasangan hidup yang berbunyi:

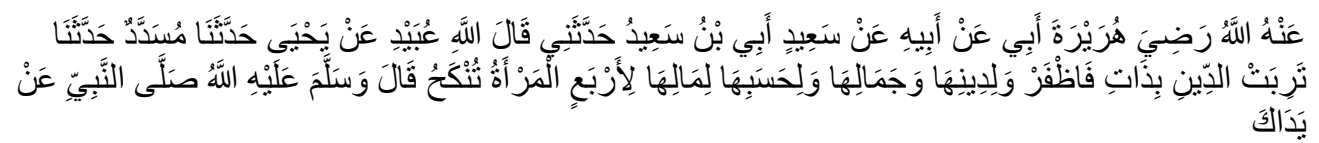

Artinya: Telah menceritakan kepada kami Musaddad Telah menceritakan kepada kami Yahya dari Ubaidullah as berkata; Telah menceritakan kepadaku Sa'id bin Abu Sa'id dari bapaknya dari Abu Hurairah radliAllah Subhanu Wa Ta'alau 'anhu, dari Nabi shall Allah Subhanu Wa Ta'alau 'alaihi wasallam, beliau bersabda: "Wanita itu di nikahi karena empat hal, karena hartanya, karena keturunannya, karena kecantikannya dan karena agamanya. Maka pilihlah karena agamanya, iniscaya kamu akan beruntung." (HR. Bukhari No.4700)

Menurut Badan Peradilan Umum Agama dalam website databoks.co.id pada tahun 2018 perceraian di ndonesia semakin meningkat setiap tahunnya. Mereka mencatat perceraian di indonesia mencapai 408.202 kasus, meningkat 9\% dibandingkan tahun sebelumnya. Penyebab perceraian pada tahun 2018, yang pertama adalah faktor ketidakharmonisan yaitu sebanyak 183.085 perkara, faktor ekonomi menempati urutan kedua sebanyak 110.909 perkara, sementara masalah lainnya adalah suami atau stri pergi $(17,55 \%), \operatorname{KDRT}(2,15 \%)$ dan mabuk $(0,85 \%)$. Hal ini menjadi salah satu krisis keluarga yang teritung dalam RUU Ketahanan Keluarga tentang perceraian dalam pasal 74 ayat 3c. informasi tersebut memberikan Lesson learned dan dapat menjadi rujukan dalam memperioritaskan komponen-komponen penting yang perlu diberikan dahulu dalam program pranikah.

Kesimpulan dari data di atas adalah penyebab perceraian bukanlah hanya dari faktor ekonomi saja, dalam hal ini faktor ekonomi menempati urutan kedua. Faktor utama penyebab perceraian adalah tidak ada keharmonisan dalam rumah tangga yang ditandai dengan perselisihan secara terus menerus dan tidak ada upaya untuk berdamai dalam memecahkan masalah sehingga perceraian menjadi jalan keluarnya.

Faktor yang kedua yaitu faktor ekonomi, selama ini yang terjadi di masyarakat ketika orang akan menikah, ekonomi atau finansial mendapatkan penekanan yang lebih besar dibandingkan faktor-faktor lainnya. Para orang tua umumnya akan menanyakan kepada orang yang akan melamar anaknya apakah mereka sudah mempunyai pekerjaan, apa pekerjaannya, 
berapa penghasilannya dan seterusnya. Pekerjaan tersebut yang menginformasikan kesiapan finansial seseorang dalam menjalani kehidupan berkeluarga.

Penelitian ini bertujuan untuk menggali syarah hadits riwayat imam Bukhari tentang memilih pasangan hidup menurut para Muhaditsin, menggali esensi kriteria dalam memilih pasangan hidup menurut hadits riwayat imam Bukhari, mengemukakan pendapat para ahli mengenai kriteria memilih pasangan dan kaitannya dengan pendidikan pranikah, serta mengidentifikasi implikasi dalam memilih pasangan hidup yang terkandung dalam hadits riwayat imam al-Bukhari terhadap pendidikan pranikah.

\section{B. Metodologi}

Penelitian ini menggunakkan pendekatan kualitatif. Menurut Sugiyono (2011:15) menyimpulkan bahwa metode penelitian yang berlandaskan pada filsafat postpositivisme, digunakan untuk meneliti pada kondisi obyek alamiah, dimana peneliti adalah sebagai instrument kunci, pengambilan sampel sumber data dilakukan secara purposive dan snowbaal, teknik pengumpulan dengan trianggulasi (gabungan), analisis data bersifat induktif atau kualitatif, dan hasil penelitian kualitatif lebih menekankan makna dari pada generalisasi.

Bentuk penelitian kualitatif yang digunakkan disini bercirikan deskriptif analitik. Penelitian deskriptif menurut Suharsimi Arikunto (2005:234) merupakan penelitian yang dimaksudkan untuk mengumpulkan informasi mengenai status suatu gejala yang ada, yaitu keadaan gejala menurut apa adanya pada saat penelitian dilakukan.

Dengan menggunakkan teknik penelitian hadits yaitu;

1. Metode Tautsiq

Metode ini digunakkan untuk mencari keotentikan hadits dengan cara mencari keberadaan hadits tersebut didalam kitab aslinya.

2. Metode Tashih

Metode ini digunakkan untuk mencari keabsahan hadits dengan cara mencari komentar hadits tersebut.

3. Metode Takhrij

Metode ini digunakkan untuk mencari dari siapa, kesiapa, dan oleh siapa hadits tersebut bersandar.

4. Metode Tarikh

Metode ini digunakkan untuk mencari sejarah atau kisah dari hadits tersebut.

5. Metode Tahlili

Metode ini digunakkan untuk mencari makna atau isi kandungan hadits.

6. Metode Takwil

Metode ini digunakkan untuk mencari brah atau pelajaran yang terkandung dalam hadits tersebut.

7. Metode Tathbiq

Metode ini digunakkan untuk mencari makna tersirat atau tersurat yang dapat dimplementasikan dalam kehidupan sehari-hari. H.U. Saifuddin (2017: 255-271).

\section{Pembahasan dan Diskusi}

\section{Analisis Esensi dari Hadits Bukhari tentang kriteria memilih pasangan}

Secara Manusiawi Seorang Laki-Laki Atau Wanita Dapat Tertarik Oleh Lawan Jenis Karena Harta, Kecantikan Atau Ketampanan, Keturunan, Dan Keberagamaan.

Dalam hadits di atas Kriteria memilih pasangan hidup dapat dilihat dari empat hal diantaranya:

1. Harta

Harta menjadi salah satu faktor pertimbangan dalam memilih pasangan. Baik dari sisi wanita yang akan mencari suami maupun laki-laki yang mencari istri. Karena harta merupakan modal dasar seseorang dalam menghidupi kehidupan rumah tangganya. Seorang wanita yang mempunyai kekayaan namun tidak mempunyai keluhuran akhlak, dapat membawa dirinya kedalam sikap sombong dan rasa ingin berkuasa maka hal 
tersebut dapat megeruhkan suasana kehidupan suami istri serta mengancamkan keutuhan rumah tangga.

Ajaran Iislam selalu mendahulukan agama di atas harta dan kekuasaan seperti firman Allah dalam qs. An-Nur ayat 32 :

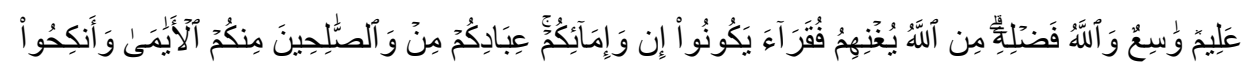

Terjemah: "Dan kawinkanlah orang-orang yang sendirian diantara kamu, dan orangorang yang layak (berkawin) dari hamba-hamba sahayamu yang lelaki dan hamba-hamba sahayamu yang wanita. Jika mereka miskin Allah akan memampukan mereka dengan karunia-Nya. Dan Allah Maha luas (pemberian-Nya) lagi Maha Mengetahui."

Ayat i ini menjelaskan, anjuran menikahi orang miskin yang bertakwa dan mempunyai pengetahuan agama yang cukup. Dalam tafsir Al-Muyasar "Dan nikahkanlah wahai kaum beriman orang-orang yang belum memiliki istri (bujangan) dan wanita-wanita merdeka yang belum memiliki suami di antara kalian, dan nikahkanlah orang-orang yang layak menikah dari hamba-hamba sahayamu yang lelaki dan wanita. Jika mereka miskin, Allah akan memampukan mereka dengan karunia-Nya yang sangat luas. Allah Maha luas rezeki-Nya. Rezekinya-Nya sama sekali tidak berkurang karena diberikan kepada seorang manusia. Dia Maha Mengetahui keadaan hamba-hamba-Nya."

2. Kecantikan (cantik lahir dan batin)

Dalam memilih pasangan dapat dilihat dari segi kecantikannya. Cantik disini bukan hanya sekadar cantik dari fisiknya (lahiriah) saja akan tetapi dilihat dari segi akhlak atau perilaku (bathiniah) baik terhadap dirinya sendiri, orang tuanya dan orang disekitarnya. Kecantikan seorang wanita jika tidak dilindungi dengan pengetahuan agama dan keturunan yang baik, akan sangat membahayakan kehormatan dirinya. Dia akan mudah terbujuk oleh orang pergaulan negatif yang dapat membawanya kelembah penghancran diri, seperti terjerumus pada pelacuran. Hal tersebut akan menjadi aib dan menodai dirinya serta keluarganya.

3. Keturunan

Keturunan menjadi salah satu hal yang penting dalam memilih pasangan, karena orang yang berasal dari keluarga yang baik dapat menghasilkan anak yang baik. Namun tidak semua yang berasal dari keturunan baik meurun pada anaknya. Jadi tetap saja baik atau tidaknya seseorang kembali pada dirinya masing-masing.

Keturunan yang baik sering dibaratkan dengan keluarga terhormat, keluarga terhormat bukan yang dipandang dari popularitas, harta, dan status sosial yang disandang oleh keluatga tersebut. Namun maksudnya adalah kemuliaan, kesucian, dan beragama.

4. Agama

Agama diartikan sebagai komitmen moral akan nilai-nilai kebaikan dalam berumah tangga. Komitmen ini menjadi pondasi dalam mengarungi bahtera rumah tangga jika terjadi permasalahan di kemudian hari. Seperti yang telah di tertulis dalam QS. Ar-Rum ayat 30:21 agama merupakan komitmen dua calon pasangan suami istri untuk selalu menciptakan ketentraman "sakinah", serta menghidupkan rasa kasih dan sayang "mawaddah wa rahmah".

Iislam mengajarkan untuk mengutamakan faktor keberagamaan sebagai kriteria pemilihan pasangan hidup dalam membangun rumah tangga. Manusia yang beragama membutuhkan pasangan yang beragama juga. Beragama dapat diartikan berpegang teguh secara utuh pada ajaran agama islam. Menerima serta menaati ajaran islam dengan jiwa dan hati, bukan beragama yang hanya terlihat dari kulitnya saja atau hanya tampak dari luar yang tidak memiliki dasar dan pengamalan.

Sebagaimana yang dituliskan dalam hadits Ibnu Majah, Al-bazzar dan Al-Baihaqi dan hadits Abdullah bin Amr secara marfu':

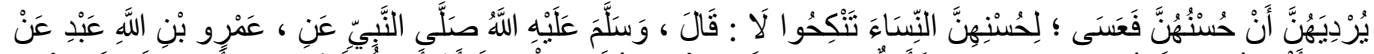

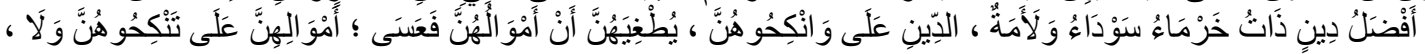

"Janganlah kamu menikahi wanita karena kecantikannya, karena hal yang itu bisa menjeremuskan mereka dalam kebinasaan dengan bersikap sombong dan takabur; dan jangan 
pula kamu menikahi mereka karena hartanya, karena hal itu bisa menjerumuskan mereka dalam perbuatan maksiat dan dosa; dan nikahilah mereka karena agamanya. Ketahuilah, sesungguhnya budak wanita yang beragama walaupun telinga sobek lebih utama dari pada wanita cantik tetapi tidak beragama."

Seorang disebut benar-benar beragama adalah ketika seluruh perbuatan, pembicaraan, akhlak, dan seluruh urusan hidupnya sesuai dengan ajaran agama islam. islam adalah peraturan atau undang-undang ciptaan Allah Subhanahu wa Ta'ala untuk kebahagiaan umat manusia. Maka dari itu dengan beragama akan memberikan manfaat bagi manusia, yang diibaratkan agama adalah batang yang hasilnya ialah berbagai ranting dan cabang.

\section{Implikasi Pendidikan Pranikah}

Pernikahan memiliki makna yang dalam bagi umat islam. Pernikahan bukan sekadar pemenuhan kebutuhann manusia sebagai makhluk sosial semata, akan tetapi juga merupakan aktivitas ibadah kepada tuhannya, maka dari itu pernikahan memiliki dua dimensi. Dimensi duniawi yaitu hubungan yang berkaitan manusia sebagai makhluk sosial dan dimensi ukhrawi yaitu hubungan yang berkaitan manusia dengan tuhannya.

Islam menjelaskan bahwa pernikahan adalah sebuah ikatan antara laki-laki dan wanita yang memiliki tujuan membangun rumah tangga yang sakinah mawaddah warahmah seperti yang dijelaskan dalam firman Allah Subhanahu wa Ta'ala dalam QS Ar-Rum ayat 30:21

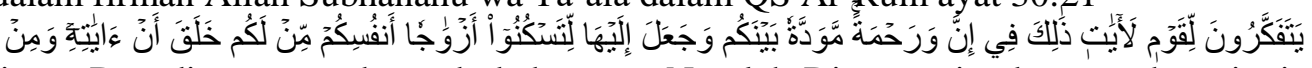

Artinya: Dan diantara tanda-tanda kekuasaan-Nya lah Dia menciptakan untukmu istriistri dari jenismu sendiri, supaya kamu cenderung dan merasa tenteram kepadanya, dan dijadikanNya diantaramu rasa kasih dan sayang. Sesungguhnya pada yang demikian itu benar-benar terdapat tanda-tanda bagi kaum yang berfikir.

(Dan diantara tanda-tanda kekuasaan-Nya ialah Dia menciptakan untuk kalian istri-istri dari jenis kalian sendiri) Siti Hawa tercipta dari tulang rusuk Nabi Adam sedangkan manusia yang lainnya tercipta dari air mani laki-laki dan perempuan (supaya kalian cenderung dan merasa tenteram kepadanya) supaya kalian merasa betah dengannya (dan dijadikan-Nya di antara kamu sekalian) semuanya (rasa kasih sayang. Sesungguhnya pada yang demikian itu) hal yang telah disebutkan itu (benar-benar terdapat tanda-tanda bagi kaum yang berpikir) yakni yang memikirkan tentang ciptaan Allah swt.

Tujuan pendidikan pranikah dalam menjalankan kehidupan berumah tangga diadakan untuk memberikan pengetahuan, pemahaman serta keterampilan mengenai pernikahan, sebelum pernikahan tersebut dilakukan oleh calon pengantin. Pendidikan pranikah ini menjadi bekal agar mampu menjalani kehidupan berumah tangga. Maka dari itu bekal untuk menjalankan rumah tangga diperlukan beberapa persiapan calon pasangan suami istri yang akan menikah perlu memperhatikan beberapa hal yaitu;

1. Persiapan fisik

2. Persiapan Material

3. Persiapan sosial

Manfaat materi pendidikan pranikah dalam mengatasi problematika kehidupan rumah tangga diantaranya:

1. Memahami kebutuhann keluarga

2. Problematika dalam memenuhi kebutuhann rumah tangga

3. Strategi dalam pemenuhan kebutuhann keluarga

4. Mengelola konflik keluarga

5. Mengetahui hak dan kewajiban sebagai suami dan istri

6. Cara berkomunikasi yang baik antar suami istri

7. Mengetahui kesehatan reproduksi

8. Penyimpangan seks

Keutamaan memilih pasangan adalah setiap muslim memiliki keinginan untuk mendapatkan suami yang saleh dan istri yang salehah, maka dari tiu diupayakan agar dirinya menjadi saleh atau sholehah terlebih dahulu. Untuk menjadikan diri seorang muslim yang saleh dan salehah, maka bekalilah diri dengan ilmu-ilmu agama, hiasilah dengan akhlak terpuji, dengan 
tujuan tidak untuk mencari jodoh semata akan tetapi untuk beribadah mendapatkan rida-Nya. Dan pernikahan merupakan salah satu media sebagai sarana untuk beribadah.

Suami istri yang saleh dapat mendatangkan manfaat bagi dirinya, anak-anaknya, dan lingkungannya. Sehingga dari dirinya tercermin perilaku dan perbuatan yang bisa menjadi teladan bagi anak-anaknya maupun orang lain. Anak yang baik dalam artian mempunyai akhlak mulia, pintar, serta sehat jasmani dan rohaninya mereka terlahir dari keluarga yang baik, karena akhlak dan kecerdasan anak itu diturunkan dari orangtuanya.

\section{Kesimpulan}

Setelah mengkaji dan menganalisis isi kandungan dari hadits riwayat Bukhari tentang kriteria memilih pasangan dan kaitannya dengan pendidikan pranikah, maka dapat diambil kesimpulan Sebagai berikut:

1. Hadits riwayat Bukhari tentang kriteria memilih pasangan tersebut menceritakan memilih pasangan dilihat dari empat hal yaitu kekayaan, keturunan, kecantikan dan agama. Pilihlah karena agamanya agar berunitung. Laki-laki itu boleh memilih wanita dengan orientasi apapun, baik secara duniawi maupun ukhrowi, di dalam hadits disebutkan bahwa wanita di nikahi karena memiliki empat sifat, keempat sifat tersebut menjadi daya tarik laki-laki untuk menikahinya. Akan tetapi terdapat sebuah himbauan bagi para pria agar lebih mengutamakan faktor agamanya. Hadits tersebut menjadi panduan bagi para laki-laki dalam memilih calon pasangan hidupnya. Di mana seorang laki-laki tidak seharusnya menjatuhkan pilihannya dikarenakan faktor duniawi semata, melainkan perlu dipertimbangkan juga faktor komitmen agamanya. Hadits tersebut juga berisi anjuran agar mencari pasangan yang berasal dari keturunan yang baik. Namun jika faktor keituruna ini bertentangan dengan faktor agama, maka yang harus diutamakan adalah faktor agama. Begitu juga dengan faktor-faktor lainnya, jika bertentangan satu sama lain, maka yang harus didahulukan adalah faktori agamanya.

2. Esensi yang terkandung dalam hadits riwayat Bukhari tentang kriteria memilih pasangan hidup yaitu sebagai berikut: Pertama, Secara manusiawi seorang laki-laki atau wanita dapat tertarik oleh lawan jenis karena harta, kecantikan atau ketampanan, keturunan dan keberagamaan. Kedua, islam mengajarkan untuk mengutamakan faktor keberagamaan sebagai kriteria pemilihan pasangan hidup dalam membangun rumah tangga.

3. Pendapat para ahli tentang pendidikan pranikah. Pendidikan pranikah merupakan proses untuk memberikan pengetahuan, pemahaman serta keterampilan mengenai pernikahan, sebelum pernikahan tersebut dilakukan oleh calon pengantin. Pendidikan pranikah ini menjadi bekal agar mampu menjalani kehidupan berumah tangga.

4. Implikasi pendidikan yang dapat diambil dari Hadits Riwayat Bukhari tentang kriteria memilih pasangan adalah sebagai berikut: Pertama, Tujuan Pendidikan Pranikah dalam Menjalankan Kehidupan Berumah Tangga. Kedua, Manfaat Materi Pendidikan Pranikah dalam Mengatasi Problematika Kehidupan Rumah Tangga. Ketiga, Keutamaan dalam memilih pasangan.

\section{Daftar Pustaka}

[1] Arikunto, Suharsimi. Manajemen Penelitian. Jakarta: Rineka Cipta, 2005.

[2] Al-Qardawi, Yusuf. Kiat Memilih Pasangan Hidup . Jakarta: Zikrul Hakim, 2005.

[3] Dr.Sugiyono. Metode Penelitian Kuantitatif, Kualitatif, R\&D. Bandung : Alfabeta, 2016

[4] ASM, H.u saepuddin. Ilmu Hadits dan Cara Berteladan Pada Rasul. Bandung: Munkaha, 2017. 